\title{
Circuit
}

Musiques contemporaines

\section{Tu es musique}

\section{Joséphine Bacon}

Volume 29, numéro 3, 2019

URI : https://id.erudit.org/iderudit/1066494ar

DOI : https://doi.org/10.7202/1066494ar

Aller au sommaire du numéro

\section{Éditeur(s)}

Circuit, musiques contemporaines

\section{ISSN}

1183-1693 (imprimé)

1488-9692 (numérique)

Découvrir la revue

Citer ce document

Bacon, J. (2019). Tu es musique. Circuit, 29(3), 108-108.

https://doi.org/10.7202/1066494ar

Ce document est protégé par la loi sur le droit d'auteur. L'utilisation des services d'Érudit (y compris la reproduction) est assujettie à sa politique d'utilisation que vous pouvez consulter en ligne.

https://apropos.erudit.org/fr/usagers/politique-dutilisation/
Cet article est diffusé et préservé par Érudit.

Érudit est un consortium interuniversitaire sans but lucratif composé de l'Université de Montréal, l'Université Laval et l'Université du Québec à Montréal. Il a pour mission la promotion et la valorisation de la recherche. https://www.erudit.org/fr/ 


\section{Tu es musique}

Joséphine Bacon



Spectacle Trancestal, 2015. Crédit: Carlos Robio.

[ndlr] Ce poème est extrait du recueil Un thé dans la toundra/Nipishapui nete mushuat de la poète innue Joséphine Bacon, publié en 2013 aux éditions montréalaises Mémoire d'encrier. En 2015, Joséphine Bacon avait participé au spectacle Trancestral, cosigné par Katia Makdissi-Warren et Moe Clark, dans le cadre des 25 ans du festival Présence autochtone.

Tu es musique

Tes nuages sont sans frontières

Quand ils s'approchent

Leurs odeurs se parfument de brume

Tu danses la pureté des gouttes

Les yeux éteints

Je perçois ta beauté

Tes mélodies

Je dépose du tabac

En offrande sur une pierre

Je te suis redevable

Pour ma liberté
Nipeten nikamun nishtikuanit

Kashkuanat mishitueiepanuat

E tatshishkakaui mushuau-assinu

Uitshimatam ${ }^{u}$ eshimakuannit

Tshinimin, minuenitam ${ }^{u}$ uapitsheushkamik"

Peikuan eka uapiani

Nitshisseniten menuashit anite etain

Ashini nipatshitinimuau

Tshishtemaua

Tshuitamun

Apu auen tipenimit 